\title{
The Impact of secondary Macro Nutrients on Crop Production.
}

\author{
Demsew Bekele*and Muluadam Birhan \\ Bahir Dar University, College Of Agriculture and Environmental Sciences, Department of Natural Resource \\ Management, P.O.Box.5501, Bahir Dar, Ethiopia.

\begin{abstract}
*Corresponding Authors: Demsew Bekele, Bahir Dar University, College Of Agriculture and Environmental Sciences, Department of Natural Resource Management, P.O.Box.5501 , Bahir Dar , Ethiopia.
\end{abstract}

\begin{abstract}
Secondary macronutrients are less commonly yield limiting than the primary macronutrients $(N, P$, and $K)$, yet are required by crops in relatively large amounts. Sulfur $(S)$, calcium $(\mathrm{Ca})$, and magnesium $(\mathrm{Mg})$ are considered secondary macronutrients because they are less commonly yield limiting than the primary macronutrients (N, P, and $K)$, yet are required by crops in relatively large amounts. Sulfur is the fourth major nutrient and it is essential for plant growth. It is essential for the formation of certain amino acids, proteins, and oils; is a structural component of protoplasm. Calcium, a structural component of plant cell walls, is most abundant in plant leaves. It is involved in cell growth, both at the plant terminal and at the root tips, and apparently enhances uptake of nitrate- $\mathrm{N} . \mathrm{Mg}$ plays a critical role in nearly all parts of plant metabolism and protein synthesis, and is an essential constituent of chlorophyll. Mg is less required by Plants than Ca.Plant growth will take place normally until it is restricted by the supply of an essential nutrient. A deficiency of any essential nutrient cannot be corrected by the addition of other crop inputs. Excess of one plant food element may cause deficiency of another. Excess of $N$ causes $K$ starvation in certain crops. Short supply of any nutrient leads to adverse cellular metabolism, growth and development of plants. Such plants bear abnormal symptoms termed as visual deficiency symptoms. Toxic conditions such as excessive soil acidity may prevent plant roots from growing or perhaps nutrients are simply in low supply. Nutrients are essential for the metabolism of crop plants hence growth and yield as well as can be considered as an important component in plant-disease interactions.
\end{abstract}

Keywords: Secondary macronutrients, Sulfur (S), calcium (Ca), and magnesium (Mg), Toxic, Nutrients

\section{INTRODUCTION}

Soil is one of the factors of plant growth. Terrestrial plants have the following demands on soil: water, air, nutrients, and protection from toxins. Plants need adequate air, water, and nutrients in their root zone for optimum growth and yield (Foth HD,1990). Crop production and productivity can be improved by the combination of genotype, optimum environmental condition and appropriate management practices which can be generalized by the formula: Yield $=\mathrm{G}$ (genotype) $\mathrm{x} E$ (environment) x M (management). The genotype refers to healthy seeds of high yielding verities; environment refers to the soil's physical and chemical properties and climate in the particular location; and management refers to the farmers' ability and skill in managing crops and the farming system (Yihenew G.Selassie, 2015).

Soil fertility is a complex quality of soils that is closest to plant nutrient management. It is the component of overall soil productivity that deals with its available nutrient status, and its ability to provide nutrients out of its own reserves and through external applications for crop production. It combines several soil properties (biological, chemical and physical), all of which affect directly or indirectly nutrient dynamics and availability. Soil fertility is a manageable soil property and its management is of utmost importance for optimizing crop nutrition on both a short-term and a longterm basis to achieve sustainable crop production (Khan Towhid Osman, 2013).

Nutrient is one of the main factors of plant growth and productivity. Plants have some other demands on soil (such as water, oxygen, and warmth) as well. If the soil has the capacity to meet all these demands of plants satisfactorily, it is a productive soil. A fertile soil is, therefore, not always productive. Soil fertility is different from soil productivity. Soil productivity is the ability of a soil to produce desired yield of crops under optimum management. Soil fertility is one of the elements of soil 
productivity (Khan Towhid Osman, 2013).

Seventeen chemical elements such as C, H, O, N, P, S, K, Ca , Mg, Fe, Mn, Cu, Mo, B, Zn, Cl, and Ni have so far been recognized as essential. Plants cannot complete their life cycles and accomplish normal physiological functions in the absence of these nutrients. Growth and yield of crops are reduced by their deficiencies. sodium $(\mathrm{Na})$, silicon $(\mathrm{Si})$, vanadium $(\mathrm{V})$, iodine $(\mathrm{I})$, and cobalt $(\mathrm{Co})$, reckoned to be beneficial for growth of certain plants and microorganisms. These inadequacies are met by the application of fertilizers (Khan Towhid Osman,2013).

From the 17 essential elements carbon $(\mathrm{C})$, hydrogen $(\mathrm{H})$ and oxygen $(\mathrm{O})$ are the non-mineral nutrients because they are derived from the air and water (Jones $C$ and J Jacobsen 2001). The remaining 14 mineral nutrients include six macronutrients: nitrogen $(\mathrm{N})$, phosphorus $(\mathrm{P})$, potassium $(\mathrm{K})$, calcium $(\mathrm{Ca})$, magnesium $(\mathrm{Mg})$, and Sulphur $(\mathrm{S})$; and eight micronutrients: boron $(\mathrm{B})$, chlorine $(\mathrm{Cl})$, copper $(\mathrm{Cu})$, iron $(\mathrm{Fe})$, manganese $(\mathrm{Mn})$, molybdenum $(\mathrm{Mo})$, nickel $(\mathrm{Ni})$ and zinc $(\mathrm{Zn})$ (Brady $\mathrm{NC}$ and RR Weil, 2008). Other nutrients that do not fall within the list of 17 essential elements but are needed in specific cases are referred to as beneficial elements (Jones C and J Jacobsen (2001) Each of the nutrients is needed in different amounts and carries specific functions in the plant. Depending on the amount that is available for plant uptake, these nutrients influence crop yields and quality. Some crop quality attributes influenced by the nutrients include; sugar and protein content, seed size, kernel size, fruit color, flavour, vitamin levels and grain hardness (Blumenthal J, 2008). Nutrients obtained from crops and crop products, for example nitrogen, sulphur, and phosphorus, are constituents of various types of proteins and protein enzymes, which are important for building plant tissues and activating various metabolic processes respectively (Soetan KO, Olaiya OC and OE Oewole, 2010).

Sulfur $(\mathrm{S})$, calcium $(\mathrm{Ca})$, and magnesium $(\mathrm{Mg})$ are considered secondary macronutrients because they are less commonly yield limiting than the primary macronutrients $(\mathrm{N}, \mathrm{P}$, and $\mathrm{K})$, yet are required by crops in relatively large amounts. Although most soils in Montana and Wyoming contain adequate secondary nutrients for crop production, $\mathrm{S}$ deficiencies are on the rise both in the region and throughout the world (Rasmussen and Kresge, 1986).

\section{Objective}

The main objective of this paper is to review the role of secondary macronutrients on crop production.

\section{Methodology}

This review paper was taken from different literatures, books, websites and scientific journals which are related to the roles of secondary macro nutrients.

\section{RESULT ANDDESSCUSION}

\section{SDESCRIBTION OFSECONDARY MACRO NUTRIENTS IN CROP PRODUCTION}

Nutrients of Plant are either chemical elements or generally compounds which are essential for growth, development, and better yield while also playing counter roles in external activities and metabolism of plants (Vitousek 1982; Alam 1999; Subbarao et al. 2003; He and Yang 2007). Studies related to nutrient's essentialities for plants were started from sixteenth and seventeenth centuries by renowned chemists Van Helmont, Boyle, Glauber, and Mayow (Street and Opik 1970).Secondary macronutrients are less commonly yield limiting than the primary macronutrients $(\mathrm{N}, \mathrm{P}$, and $\mathrm{K})$, yet are required by crops in relatively large amounts. Although most soils in Montana and Wyoming contain adequate secondary nutrients for crop production, $\mathrm{S}$ deficiencies are on the rise both in the region and throughout the world (Rasmussen and Kresge,1986).

The $19^{\text {th }}$ century saw an emergence of agricultural chemistry and witnessed the use of artificial fertilizer for improving the crop quality and yield. Furthermore, with the progress of water and sand culture techniques, appreciation of elements which are essential for plants was also discovered, and the essentialities of nitrogen $(\mathrm{N})$, phosphors $(\mathrm{P})$, sulfur $(\mathrm{S})$, potassium $(\mathrm{K})$, calcium $(\mathrm{Ca})$, magnesium $(\mathrm{Mg})$, and iron $(\mathrm{Fe})$ for the plants were identified (Street and Opik 1970). Through the systematic development of elemental research, it has been shown that some plants complete their life cycle in the presence of various elements; however, in their absence, plants were incapable. Therefore, Epstein (1972) has classified elemental requirement in two ways, i.e., essential and nonessential elements.

\section{Role of Sulfur on cropproduction}


Sulfur is the fourth major nutrient and it is essential for plant growth .It is essential for the formation of certain amino acids, proteins, and oils; is a structural component of protoplasm; and is necessary for activation of certain vitamins and enzymes (Havlin, et al 2005).It also used in the synthesis of amino acids required to manufacture proteins. It required for production of chlorophyll and utilization of phosphorus and other essential nutrients. Sulfur ranks equal to nitrogen for optimizing crop yield and quality. It increases the size and weight of grain crops and enhances the efficiency of nitrogen for protein manufacture. Crops that have a high nitrogen requirement must have adequate sulfur to optimize nitrogen utilization. Sulfur increases yield and protein quality of forage and grain crops along with production and quality of fiber crops (M. Ray Tucker, 1999).

Sulphur (S) is an important constituent of a number of amino acids, the building blocks of proteins, and vitamins that are vital to both plants and animals. In plants, $\mathrm{S}$ is required for photosynthesis, and is also closely associated with nitrogen in many plant processes. There is no soil test available to accurately predict $\mathrm{S}$ deficiency in soils. The $\mathrm{S}$ content and the $\mathrm{N}$ to $\mathrm{S}(\mathrm{N}: \mathrm{S})$ ratio in plants are useful guides to assessing the likelihood of a response to $S$ fertilizers. The $S$ content should be greater than $0.2 \%$ in dry matter, and the N:S ratio should be less than 15:1 (Stephen Alexander et al, 2016).

\section{Role of Calcium on cropproduction}

The main important role $\mathrm{Ca}$ is for cell elongation and maintaining membrane of $\mathrm{Ca}$ in soil solution can be ten times larger than $\mathrm{K}$ and plants require much less $\mathrm{Ca}$, so deficiencies are rare. Mass flow supplies adequate $\mathrm{Ca}$ to plant roots, except in low $\mathrm{Ca}$ soils, where diffusion becomes an important process. $\mathrm{Ca}$ is usually the dominant base cation in exchange reactions, accounting for more than $70 \%$ of base saturation. Base saturation represents the percentage of the CEC occupied by base cations (Ca, $\mathrm{Mg}, \mathrm{K}$, and $\mathrm{Na}$ ) and generally increases with $\mathrm{pH}$. Exchangeable $\mathrm{Ca}$ exists in equilibrium with the soil solution, replenishing soluble Ca losses by plant uptake or leaching (Nathan Korb, et.al 2002)

Calcium, a structural component of plant cell walls, is most abundant in plant leaves. It is involved in cell growth, both at the plant terminal and at the root tips, and apparently enhances uptake of nitrate$\mathrm{N}$. Calcium is not translocated within the plant, so an adequate supply throughout the season is important for sustained terminal and root growth. Cotton roots will not grow into a soil area unless it has adequate $\mathrm{Ca}$ (Hodges,S.C.(n.d).

Calcium is an essential nutrient that has varied functions within plants. and is absorbed by plants as the $\mathrm{Ca}^{++}$ion. Inside the plant it performs several functions: Maintains strength of cell wallsand reduces lodging, Regulates uptake of other elements, Regulates cell sap $\mathrm{pH}$ and neutralizes acids produced by plants and Essential for activity of Rhizobium. Calcium is the predominant positively charged ion $\left(\mathrm{Ca}^{++}\right)$on soil particles because it is held more tightly than magnesium $\left(\mathrm{Mg}^{++}\right)$and potassium $\left(\mathrm{K}^{+}\right)$. Also, the soil parent material usually contains much more calcium than magnesium or potassium (Havlin, et al ,2005).

Calcium $(\mathrm{Ca})$ is one of the Second macronutrient essential for all plants. The ability of a soil to supply this element is intimately tied to soil acidity because calcium is the main nonacid cation that reduces aluminum saturation and is a major constituent of most liming materials used to raise soil $\mathrm{pH}$. The calcium status of soils has a major influence on the species composition and productivity of terrestrial ecosystems. For animals, the calcium content of the plants they eat is important because calcium is a major component of bones and teeth and plays important roles in many physiological processes. Before the application of calcium transformed the region into the thriving center of South America's agricultural economy, the acid soils of the Brazilian Cerrado region were so infertile that the area was considered a wasteland. The soils were so low in calcium that ranchers trying to graze herds on the Cerrado vegetation would lose cattle from broken bones due to calcium deficiency. It has even been suggested that the relatively higher calcium status of soils in Africa compared to those in South America may account for the occurrence of such large herbivores as elephants, zebras, and giraffes in semiarid savannas in Africa but not in South America (Brady and Weil, 2017).

Calcium has a role on cell walls and is involved in production of new growing points and root tips. It provides elasticity and expansion of cell walls, which keeps growing points from becoming rigid and brittle. It is immobile within plants and remains in 399 older tissue throughout the growing season. It acts as a base for neutralizing organic acids generated during the growing process and aids in carbohydrate translocation and nitrogen absorption. Indeed, calcium might be considered the bricks in plant assembly, without which cell manufacture and development would not occur (M. Ray Tucker, 
1999).

\section{Role of Magnesium on cropproduction}

Magnesium is a positively charged cation $\left(\mathrm{Mg}^{++}\right)$and as such is held on the surface of clay and organic matter particles. Magnesium is immobile in soils since it is held by soil exchange sites. acid soils often contain relatively low levels of magnesium, especially sands. Neutral soils or those with a high pH usually contain in excess of $1000 \mathrm{lbs} / \mathrm{a}$ of exchangeable magnesium (Havlin, et al ,2005).

$\mathrm{Mg}$ plays a critical role in nearly all parts of plant metabolism and protein synthesis, and is an essential constituent of chlorophyll. $\mathrm{Mg}$ is less required by Plants than $\mathrm{Ca}$, but deficiencies are more common because less $\mathrm{Mg}$ exists in the soil solution. Mineral forms of $\mathrm{Mg}$ are relatively resistant to weathering and represent a large fraction of total soil $\mathrm{Mg}$. Mineral forms of $\mathrm{Mg}$ include biotite, horneblende, olivene, dolomite, and most 2:1 clay mineral. Soluble $\mathrm{Mg}$ can also precipitate out of solution as $\mathrm{MgCO} 3$ or $\mathrm{MgSO} 4$, frequently along with $\mathrm{CaCO} 3$ in the sub-surface (Nathan Korb, et.al. ,2002). $\mathrm{Mg}^{++}$ion is the available form of Magnesium to absorb by plants. Magnesium and nitrogen are the only soil nutrients that $\mathrm{a}=\mathrm{re}$ a part of chlorophyll and is also involved in phosphorus metabolism and several plant enzyme systems (Havlin, et al ,2005).

About $15-20 \%$ of the plant $\mathrm{Mg}$ is contained in chlorophyll, without which the plant could not capture energy from the sun for growth and development. Magnesium also appears to activate a number of enzymes and plays a role in protein synthesis and phosphorus reactions. Oil seed crops have much higher seed $\mathrm{Mg}$ than cereal seed, with $\mathrm{Mg}$ and $\mathrm{S}$ apparently influencing oil formation within the seed(Hodges,S.C.(Nd).

Plants generally take up $\mathrm{Mg}$ in amounts $(0.15-0.75 \%$ of dry matter) similar to or somewhat smaller than they do Ca. About one-fifth of the magnesium in plant tissue is found as the central component of the chlorophyll molecule and so is intimately involved with photosynthesis in plants. Magnesium also plays critical roles in the synthesis of oils and proteins and in the activation of enzymes involved in energy metabolism. The $\mathrm{Mg}^{2+}$ ion forms a bridge connecting ATP molecules (which provide energy for cellular reactions) to the enzymes that catalyze numerous physiological processes involving phosphorylation (Brady and Weil, 2017).

Magnesium used as constituent of the chlorophyll molecule, which is the driving force of photosynthesis. It is also essential for the metabolism of carbohydrates (sugars). It is an enzyme activator in the synthesis of nucleic acids (DNA and RNA). It regulates uptake of the other essential elements, serves as a carrier of phosphate compounds throughout the plant, facilitates the translocation of carbohydrates (sugars and starches), and enhances the production of oils and fats. Magnesium deficiency is most prevalent on sandy coastal plain soils where the native magnesium content is low (M. Ray Tucker, 1999).

\subsection{SECONDARY MACRO NUTRIENTS IN SOIL And PLANT}

The concentration of the essential elements in plants is expressed on a dry-matter basis as either percent or grams per kilogram $(\mathrm{g} / \mathrm{kg}$ ) for the major elements, and either parts per million $(\mathrm{ppm})$ or milligrams per kilogram $(\mathrm{mg} / \mathrm{kg})$.

Table1. Principles of plant analysis (Robert d. munson, 1998)

\begin{tabular}{|l|l|l|l|l|}
\hline Major element & $\%$ & $\mathrm{~g} / \mathrm{kg}$ & $\mathrm{Cmol}\left(\mathrm{p}^{+}\right) / \mathrm{kg}$ & $\mathrm{Cmol} / \mathrm{kg}$ \\
\hline Phosphorus (P) & 0.32 & 3.2 & - & 10 \\
\hline Potassium (K) & 1.95 & 19.5 & 50 & 50 \\
\hline Calcium (Ca) & 2.00 & 20.0 & 25 & 50 \\
\hline Magnesium (Mg) & 0.48 & 4.8 & 10 & 20 \\
\hline Sulfur (S) & 0.32 & 3.2 & - & 10 \\
\hline
\end{tabular}

\section{Minimum soil cation Requirement}

Table2.Table Handbook for Integrated soil fertility Management (2012)

\begin{tabular}{|l|l|}
\hline Nutrients & Amount in $\mathrm{cmol} \mathrm{c} \mathrm{kg}^{-1}$ \\
\hline Exchangeable Calcium & $<5$ \\
\hline Exchangeable Magnesium & $<0.2$ \\
\hline Exchangeable Potasium & $<0.2$ \\
\hline
\end{tabular}

Availability and Uptake forms of Secondary macro nutrient forplants 
Plant growth will take place normally until it is restricted by the supply of an essential nutrient. A deficiency of any essential nutrient cannot be corrected by the addition of other crop inputs. This forms the basis of Liebig's "Law of the Minimum", which says that the level of crop production is limited by the nutrient in shortest supply. Crop yield is determined by the supply of individual nutrients relative to their required levels for optimal yield (Brady and Weil,2017).

The main source of plant-available $\mathrm{Mg}$ in most soils is the pool of exchangeable $\mathrm{Mg}$ on the clayhumus complex .As plants and leaching remove this $\mathrm{Mg}$, the easily exchangeable pool is replenished by $\mathrm{Mg}$ weathered from minerals (such as dolomite, biotite, hornblende, and serpentine). In some soils, replenishment also takes place from a pool of slowly available $\mathrm{Mg}$ in the structure of certain 2:1 clays. Variable amounts of $\mathrm{Mg}$ are made available by the breakdown of plant residues and soil organic matter. In unpolluted forests, research suggests that atmospheric deposition, rather than rock weathering, may supply much of the magnesium used by trees (Brady and Weil,2017).

\section{Plant uptake mechanism of Secondary macro nutrient \\ Root Interception}

Root interception is the uptake of nutrients by plant roots as they grow through the soil and incidentally come into contact with nutrients. Nutrient uptake by root interception is directly related to the volume of the root system, which in most cases is less than $1 \%$ of the total soil volume. Consequently, root interception makes a small contribution to total nutrient uptake (Nathan Korb, et al 2002).

\section{Mass Flow}

In mass flow, dissolved nutrients move with water towards root surfaces where they are absorbed. Mass flow is a significant mechanism for the uptake of some nutrients, such as nitrogen. Nutrient uptake by mass flow is reduced in dry conditions and at lower temperatures because the rate of transpirational water uptake is reduced (Nathan Korb, et al 2002)

\section{Diffusion}

Diffusion is the process by which nutrients spread from areas of high concentration to areas of low concentration. When roots absorb nutrients from soil solution the concentration of nutrients surrounding the root drops. As a result, nutrients in areas of higher concentration in soil solution migrate toward the root. Diffusion is an important process in crop uptake of $\mathrm{P}$ and $\mathrm{K}$ (Nathan Korb, et al, 2002).

\subsubsection{Cycle of Secondary Macro Nutrient}

\subsubsection{Sulfur Cycling}

Sulfur undergoes numerous transformations in the soil, involving biological, chemical, and atmospheric processes. The major forms of $\mathrm{S}$ only a small fraction of the total $\mathrm{S}$ in the soil is readily available to crops. The major processes governing $S$ availability in the soil are plant uptake, mineralization, immobilization, Exchange, volatilization, precipitation, oxidation, reduction, mineral weathering, and leaching .Soil properties such as water content, $\mathrm{pH}$, temperature, and aeration influence these processes and consequently affect the amount of $S$ available to satisfy crop requirements. Management of $\mathrm{S}$ is improved by an understanding of how these nutrient cycles in the soil and under what conditions deficiencies are likely to occur (Nathan Korb, et al 2002).

Sulfur occurs primarily in the sulfate (SO4-2) form in the soil. Elemental sulfur (S) may be used as a source of this nutrient, but it must first undergo a biological oxidation process that is dependent upon the Thiobacillus bacteria to produce sulfate. This process is produces large amounts of acid, and occasionally elemental sulfur is used to decrease soil $\mathrm{pH}$. Fertilizer materials containing sulfate do not acidify the soil, although pH may decline slightly for a short period (salt effect) (Hodges,S.C.(n.d). 


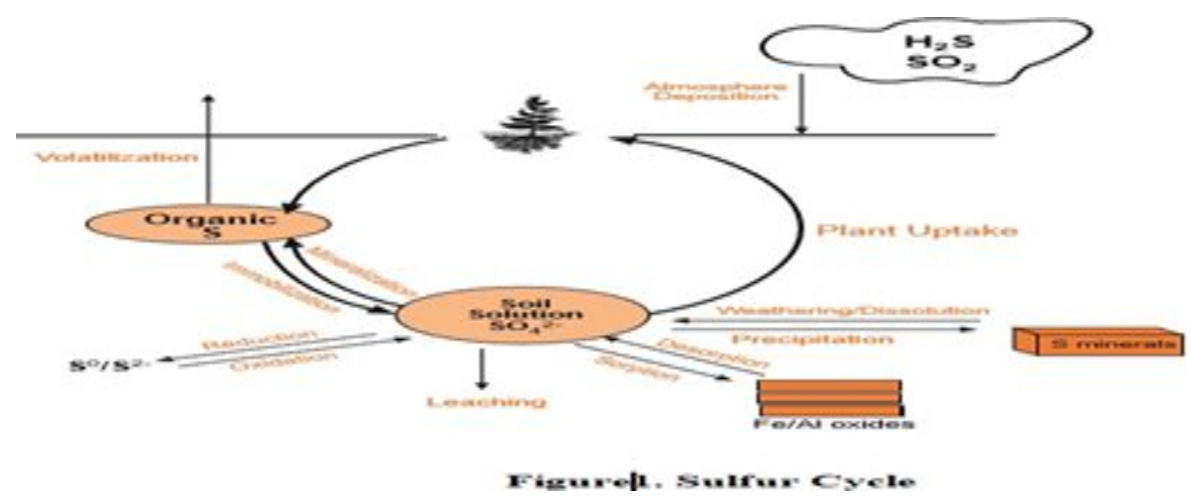

Sulfur cycles in the soil environment, much like nitrogen. Soil organic matter is an excellent source of sulfur. Plants take up sulfur as the sulfate (SO4) ion (Havlin, et al ,2005).

\section{Calcium and MagnesiumCycling}

$\mathrm{Ca}$ and $\mathrm{Mg}$ occur in the soil as soluble 'divalent' ('double-charged') cations $\left(\mathrm{Ca}^{+2}\right.$ and $\left.\mathrm{Mg}^{+2}\right)$, on cation exchange sites, and in mineral forms. The major processes in the $\mathrm{Ca} / \mathrm{Mg}$ cycle are plant uptake, exchange, precipitation, weathering, and leaching. $\mathrm{Ca} / \mathrm{Mg}$ dynamics in the soil are quite similar to $\mathrm{K}$. plants absorb the soluble ionic form from soil solution, which is then replenished by exchangeable and mineral $\mathrm{Ca} / \mathrm{Mg}$. The most notable difference between these nutrient cycles is the absence of $\mathrm{Ca} / \mathrm{Mg}$ clay fixation (Nathan Korb, et al 2002).

Calcium and magnesium behave very much the same in the soil due to similar chemical properties. Both are divalent cations, and their ionic size is about the same. The mobility of both calcium and magnesium is relatively low, especially compared to anions or even other cations such as sodium or potassium. Therefore, loss of these two cations through leaching is relatively low, especially when applied in the form of lime. Where soils are deficient in $\mathrm{Ca}$ and lime is not an alternative because of $\mathrm{pH}$ or insolubility, a more soluble source such as gypsum (calcium sulfate) should be used (Hodges,S.C.(n.d).



Interaction Of Secondary Macro Nutrients Other SoilCharacters

Excess of one plant food element may cause deficiency of another. Excess of $\mathrm{N}$ causes $\mathrm{K}$ starvation in certain crops like potato, imbalance among each element, Excess of $\mathrm{K}$ causes deficiency of $\mathrm{Mn}$ in tomato, Principles and Excess of $\mathrm{P}$ causes deficiency of $\mathrm{Zn}$ in most of the crops (SS Rana , 2011).Interactions among plant nutrients can have considerable influence on plant growth. The interplay of plant nutrients is best studied in factorial experiments that test each nutrient at three or more rates.There can be both positive and negative interactions in soil fertility studies. In addition, there can be circumstances where there is no interaction, with the action of factors being only additive (SS Rana ,2011). 
Changes in soil $\mathrm{pH}$ will result in numerous interactions where one ion or nutrient interferes with or competes with the uptake and utilization of other nutrients by plants. Positive interactions are in accordance with Liebig's law of the minimum. If two factors are limiting, or nearly so, addition of one will have little effect on growth, whereas provision of both together will have a much greater influence. In severe deficiencies of two or more nutrients, all fertilizer responses will result in strong positive interactions. Yield increases from an application of one nutrient can reduce the concentration of a second nutrient, but the higher yields result in greater uptake of the second nutrient. This is a dilution effect, which should be distinguished from an antagonistic effect. In addition to interactions between two or more nutrients, there are numerous opportunities for other kinds of interactions: for example, nutrients and disease, nutrients and cultural practice, nutrients and crop species, nutrients and hybrid or variety, nutrients and seeding date, nutrients and plant population or spacing, and nutrients and environmental conditions (SS Rana ,2011).

\section{Factors of nutrient depletion and loss of Secondary macro nutrients In thesoil}

Leaching is the physical removal of plant available $\mathrm{S}, \mathrm{Ca}, \mathrm{Mg}$ and other cations by water moving through the profile, whereas volatilization represents a biological or chemical transformation and subsequent release of $\mathrm{S}$ into the atmosphere. The areas with the highest risk for sulfate leaching are associated with high precipitation, irrigated conditions, coarse textured, shallow soils, and soils with low AEC. Irrigation following $\mathrm{SO}_{4}{ }^{-2}$ fertilizer application can move $\mathrm{SO}_{4}{ }^{-2}$ through a profile and eventually out of reach of plant roots (Nathan Korb, et al,2002).

Sulfate leaching represents an economic loss, because once the SO4-2 has left the soil system, it is no longer available for crop uptake. In semiarid climates, sulfate often collects in the subsoil, as described earlier, because there is insufficient water to flush the anion below the rooting zone of plants. Leaching losses are generally less in high $\mathrm{pH}$ soils because sulfate will precipitate with $\mathrm{Ca}$ or Mg. It should be noted that in some soils, water moving upward through the soil profile via capillary action late in the growing season can carry $\mathrm{S}$ towards the plant roots and the soilsurface. In such instances, excess $\mathrm{Ca}$ and $\mathrm{Mg}$ sulfate salts can accumulate to harmful levels in the surface and limit plant growth. Careful water management, especially in irrigated cropping systems can prevent many of the problems associated with leaching of S or the over-accumulation of S salts (Nathan Korb, et al, 2002).

Volatilization of sulfur compounds represents a relatively small loss in most agricultural soils. Generally, the amount of S volatilized from the soil is less than $0.05 \%$ of total $\mathrm{S}$ in the soil, and from live plants the release is between $0.03 \%$ and $6 \%$ of total $\mathrm{S}$ in the plant (Havlin et al., 1999). Most volatilization in the soil occurs during biological decomposition of organic residues. Biological volatilization can occur under both aerobic and anaerobic conditions, but is less significant in welldrained, well-aerated soils (Tisdale et al., 1986). Probably the most significant volatile loss of S occurs when agricultural areas are subject to fire. Although sulfate concentrations may increase due to chemical mineralization (burning) of organic S, burning dry grass has resulted in losses of $75 \%$ of total $\mathrm{S}$ in vegetative (Nathan Korb, et al, 2002).

Coarse-textured soils in humid regions exhibit the greatest potential for $\mathrm{Mg}$ deficiency. These soils normally contain small amounts of total and exchangeable $\mathrm{Mg}^{2+}$. Soils are probably deficient when they contain less than 25 to $50 \mathrm{ppm}$ exchangeable $\mathrm{Mg}^{2+}$ (SS Rana. 2011). Mg occurs predominantly as exchangeable and solution $\mathrm{Mg}^{2+}$. The absorption of $\mathrm{Mg}$ by plants depends on the amount of solution $\mathrm{Mg}^{2+}$, Soil $\mathrm{pH}$, the $\% \mathrm{Mg}$ saturation on the CEC, the quantity of other exchangeable ions and the type of clay. Reduced Mg uptake in many strongly acid soils is caused by high levels of exchangeable $\mathrm{Al}^{3+}$. Al saturation of 65 to $70 \%$ is often associated by high $\mathrm{H}^{+}$. Al saturation of 65 to $70 \%$ is often associated with Mg deficiency (SS Rana. 2011).

\section{DEFICIENCY SYMPTOM OF SECONDARY MACRO NUTRIENTS ONPLANTS}

Short supply of any nutrient leads to adverse cellular metabolism, growth and development of plants. Such plants bear abnormal symptoms termed as visual deficiency symptoms. The deficiency can be corrected or prevented by supplying that nutrient. Visual nutrient deficiency symptoms can be caused by many other plant stress factors; therefore, caution should be exercised when diagnosing deficiency symptoms. The following terms are commonly used to describe levels of nutrients in plants:

Deficient: When the concentration of an essential element is low enough to limit yield severely and 
distinct deficient symptoms are visible. Extreme deficiency can result in plant death. With moderate or slight deficiency symptoms are visible, but yields will still be reduced (Havlin, et al

,2005).

Critical range: The nutrient concentration in the plant below, which a yield response to added nutrient occurs. Critical levels or ranges vary among plants and nutrients, but occurs somewhere in the transition between nutrient deficiency and sufficiency (Havlin, et al,2005).

Sufficient: The nutrient concentration range in which added nutrient will not increase yield but can increase nutrient concentration. The term luxury consumption is often used to describe nutrient absorption by the plant that does not influence yield (Havlin, et al,2005).

Excessive or toxic: when the concentration of essential or other element is high enough to reduce plant growth and yield. Excessive nutrient concentration can cause an imbalance in other essential nutrients, which also can reduce yield (Havlin, et al,2005).

\section{General Nutrient Deficiency Symptom of plants}

Sometimes the soil chemistry is such that the soil is not able to supply sufficient nutrients to the plant. Toxic conditions such as excessive soil acidity may prevent plant roots from growing or perhaps nutrients are simply in low supply. When these conditions are severe enough, plants will exhibit nutrient deficiency symptoms. The symptoms expressed by the plant are often used tosomewhat subjectively diagnose plant nutrient problems. Some common symptoms shown by plants are:

(1) Chlorosis - Ayellowing, either uniform or interveinal, of plant tissue due to a reduction of the chlorophyll formationprocesses.

(2) Necrosis - The death or dying of plant tissue. It usually begins on the tips and edges of older leaves and also may be caused by drought, herbicides, disease, foliar application of fertilizer or animals marking territorialboundaries.

(3) Rosetting - A cluster of leaves crowded and arising from a crown, resulting from a lack of new terminalgrowth.

(4) Anthocyanin (pigment) accumulation - This results in the appearance of reddish, purple or brownish coloration. The pigment anthocyanin forms due to sugaraccumulation.

(5) Stunting or reduced growth, with either normal or dark green coloring or yellowing. The symptom location on the plant depends on how well the nutrient moves from older plant tissues to younger developing parts. Nutrients that can be moved readily by the plant (mobile nutrients) to younger developing tissue are nitrogen, phosphorus, potassium and magnesium. Deficiency symptoms for these nutrients are usually first expressed in the older leaves (Hugh Savoy,Nd).

\section{Sulfur DeficiencySymptoms}

$\mathrm{S}$ deficiency is a paleness of the younger foliage. However, often all of the foliage has a pale green color. Leaf yellowing is also caused by nitrogen deficiency, but in nitrogen deficiency, older leaves are yellowed first. In some cases, the leaf veins may be lighter in color than the surrounding tissue. Sulfur deficiency symptoms in canola include poor seed development. Sulfur deficiency delays maturity and produces mature pods on green stems, with poor seed development within the pod (Khan Towhid Osman, 2013).

Sulfur deficiency is characterized by stunted growth, delayed maturity, and general yellowing of plants. Yellowed plants are also characteristic of nitrogen deficiency. However, unlike nitrogen deficiency which begins in the older leaves and progresses up the plant, sulfur deficiency symptoms

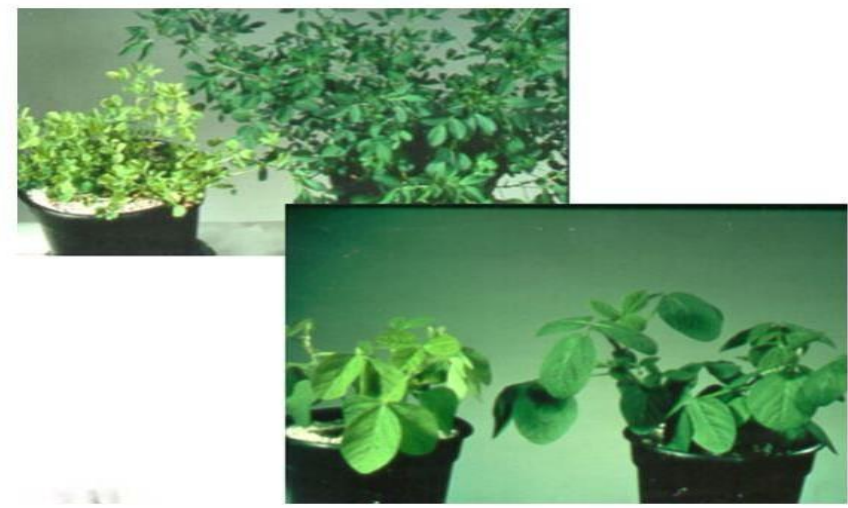


begin in the young, upper leaves first. Sulfur deficiencies are often misdiagnosed as nitrogen problems, leaving growers to wonder why their nitrogen applications are ineffective. In many crops, an acute sulfur deficiency causes the entire plant to turn yellow. In crops like corn and small grains, however, yellow stripes that run parallel to the leaf blade are common. Sulfur deficiency is most frequently observed on very sandy soils with allow organic matter content during seasons of excessive rainfall (M. Ray Tucker, 1999).

\section{Excess Sulfur}

Sulfur toxicity rarely occurs. Excess sulfate-S (SO4) can reduce the uptake of some anions such as nitrate (NO-3) and molybdate ( $\mathrm{MoO}^{-} 4$ ) (Khan Towhid Osman, 2013Calcium DeficiencySymptoms

Calcium is not a common limiting nutrient. However, there are several defects that can be associated with low levels of $\mathrm{Ca}$, including poor root development, leaf necrosis and curling. In extremely acidic soils, calcium deficiency may occur in some agronomic crops. The new leaves become often chlorotic in corn. Many fruits and vegetables demonstrate dramatic symptoms such as black heart in celery and broccoli, tip-burn in lettuce and cabbage, white heart or hollow heart in cucurbits, blossom end rot in tomatoes. Tree fruit with low calcium will exhibit increased storage problems such as bitter pit in apples, cork spot in apples and pears, and cracking in cherries (Khan Towhid Osman, 2013).

Low $\mathrm{Ca}$ content in soil often causes acidity problems before actual Ca nutrient deficiency becomes an issue. Both the role of $\mathrm{Ca}$ as a base cation and its frequent occurrence with carbonates $\left(\mathrm{CO}_{3}^{-2}\right)$ and bicarbonates $\left(\mathrm{HCO}^{3-)}\right.$ buffer soil at high $\mathrm{pH}$ levels. Where acidity is a problem, liming soils with $\mathrm{CaCO} 3, \mathrm{CaO}$, or $\mathrm{Ca}(\mathrm{OH}) 2$ is a common practice (Nathan Korb, et al, 2002).

Calcium $(\mathrm{Ca})$ deficiency symptoms appear in the meristem regions (new growth) of leaves, stems, buds, and roots. Younger leaves are affected first and are usually deformed. In extreme cases, the growing tips die. The leaves of some plants hook downward and exhibit marginal necrosis. Roots on calcium-deficient plants are short and stubby. In tomatoes and peppers, a black leathery appearance develops on the blossom end of the fruit (a disorder called blossom- end rot). In such cases, the fruit ceases to develop and eventually falls off. In peanuts, low calcium causes "pops," a condition that prevents nuts from developing. Plants must obtain calcium from the soil. Soil reserves are replenished and maintained with frequent applications of lime. Calcium can also be supplied by applying fertilizers such as calcium nitrate $(19.4 \% \mathrm{Ca})$, calcium sulfate $(22.5 \% \mathrm{Ca})$, and normal superphosphate $(20.4 \% \mathrm{Ca})$. Calcium deficiency is generally an indication of the need for lime. Soils that are properly limed will provide adequate calcium for several years. For crops like peanuts that require a high calcium concentration near the soil surface at pegging, a banded or broadcast application of gypsum $(\mathrm{CaSO} 4,22.5 \% \mathrm{Ca})$ will supply adequate calcium for normal crop production. For certain specialty crops, a foliar application of calcium nitrate is effective in correcting a deficiency (Khan Towhid Osman, 2013).

$\mathrm{Ca}^{2+}$ is usually the most abundant of the non acid cations in soils, for most plants deficiencies of calcium are quite rare, except in very acid soils. When calcium deficiency does occur, it is usually associated with growing points (meristems) such as buds, unfolding leaves, fruits, and root tips. Foliar symptoms of calcium deficiency are not commonly seen. However, they may occur in extremely acid soils where plants are likely to also suffer from aluminum toxicity and other problems. Under calcium deficiency, the root system is often shorter and denser than normal. Under such conditions, calciumdeficient roots become severely stunted and gelatinous. These root effects can cause sensitive forest trees to lose branches and eventually die. In very acid soils, Ca deficiency is often accompanied by Al or Mn toxicity, and the related effects on plants are difficult to tell apart (Brady and Weil,2017).

Certain plants show $\mathrm{Ca}$ deficiency, even when the soil $\mathrm{pH}$ is adequately maintained by liming. Such deficiencies are often related to the transport of $\mathrm{Ca}$ within the plant. Blossom-end rot is an exceptionally disheartening example. Imagine a gardener about to pick a delicious- appearing ripe tomato- only to find that the bottom (blossom-end5 of the fruit is a soft, black, rotten mass. This disorder, especially common in melons and tomatoes, is caused by inadequate $\mathrm{Ca}$ for the cell walls of the expanding fruit. It is usually associated with unevenness in the water supply that interrupts the 
flow of Ca (Brady and Weil,2017).

\section{Excess Calcium}

Calcium has little toxic effects on plants. Most of the problems caused by excess soil $\mathrm{Ca}$ are the result of secondary effects of high soil $\mathrm{pH}$. Excess $\mathrm{Ca}$ may cause reduced uptake of other nutrients such as P, K, Mg, B, Cu, Fe, and Zn (Khan Towhid Osman, 2013).
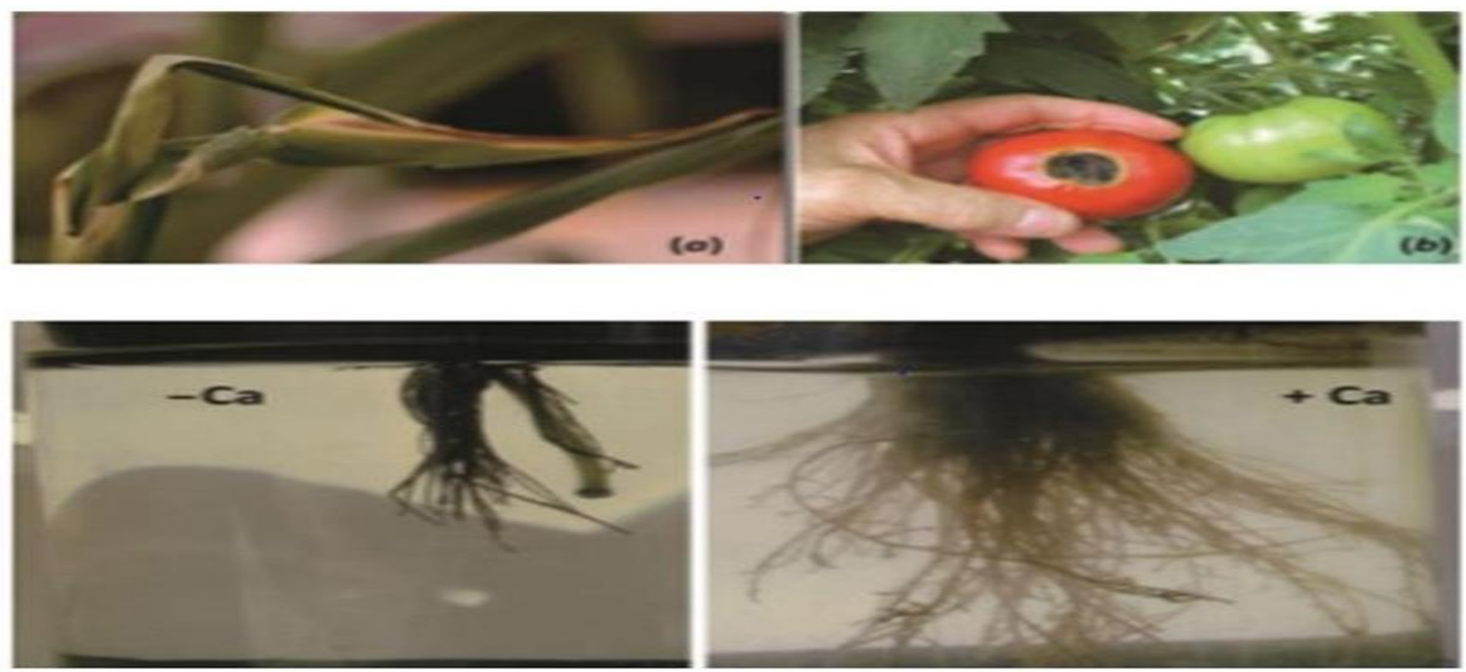

Figure4. Calcium defikiency symptom

\subsubsection{Magnesium Deficiency Symptoms}

Interveinal chlorosis of the older leaves is the classic symptom of $\mathrm{Mg}$ deficiency in plants. In the beginning, a pale green color appears, becoming more pronounced in the older leaves. In some plants, the leaves will curl upward and may also turn red-brown to purple in color. Chlorotic spots between leaf veins, necrosis (dead spots), and red discoloration of stems occur during prolonged periods of deficiency. Magnesium deficiency may be confused with zinc or chlorine deficiencies, viruses, or natural aging since all have similar symptoms (Khan Towhid Osman, 2013). Magnesium deficiency is most prevalent on sandy-textured soils, which are subject to leaching, particularly during seasons of excess rainfall. The predominant symptom is interveinal chlorosis (dark green veins with yellow areas between the veins) (M. Ray Tucker, 1999).

When deficient, $\mathrm{Mg}$ is transferred in the plant from older to new tissue. As a result, deficiency symptoms occur first in older leaves. Tissue between the veins becomes light green to whitish in color. In corn and other cereals this leads to striping between veins that may be intermittent rather than continuous. With severe deficiencies, purple coloration may follow. Cotton leaves turn purplish between the green veins (Havlin, et al 2005). The bottom leaves are always affected first. As the deficiency becomes more acute, the symptoms progress up the plant. Chlorotic leaves generally turn red and then develop spotted necrotic areas. Crops that commonly exhibit magnesium deficiency include tobacco, corn, small grains, forages, and vegetable crops. On grain crops like small grains and corn, magnesium- deficient leaves have light green to yellow stripes that run parallel with the blade. In severe cases, the entire leaf turns yellow. Magnesium deficiency is the common cause of "grass tetany" in ruminant animals. On tobacco, deficiency symptoms begin on the tips of the lower leaves and progress across the entire leaf. In acute situations, the entire plant becomes chlorotic (Nathan Korb, et al, 2002).

The deficiency of $\mathrm{Mg}$ is much more common than that of $\mathrm{Ca}$, at least when the soil $\mathrm{pH}$ is at an appropriate level. The most common symptom of $\mathrm{Mg}$ deficiency is interveinal chlorosis on the older leaves, which appears as a mottled green and yellow coloring in dicots and a striping in monocots. Because $\mathrm{Mg}$ (unlike $\mathrm{Ca}$ ) is readily translocated in most plants from the older to the younger, stillgrowing leaves, the oldest leaves are the first to be affected by low Mg supplies. Common on very sandy soils with low cation exchange capacity (CEC), these symptoms are sometimes termed sand drown as they appear somewhat like those caused by oxygen starvation in a waterlogged soil (Brady and Weil,2017). 
Deficiency symptoms generally appear after topping when the plant is growing most rapidly. The symptoms are commonly referred to as "sand drown" since they occur most frequently on very sandy soils during periods of excessive rainfall. Magnesium deficiency occurs if soil $\mathrm{pH}$ is low or if only calcitic lime has been applied. Depending on the stage of growth and crop, magnesium deficiency can be corrected by soil application of lime or fertilizer. However, once a deficiency symptom has appeared, nothing can be done to correct the affected leaves. Application of a soluble magnesium fertilizer may prevent upper leaves from developing symptoms. Foliar applications of magnesium are effective in emergency situations where immediate response is required to salvage a crop. Usually, magnesium is applied to the soil through use of commercial fertilizers or dolomitic lime. Dolomitic lime sold in N.C. must contain a minimum of $6 \% \mathrm{Mg}$. However, some quarries guarantee as much as 9\% Mg (M. Ray Tucker,1999).

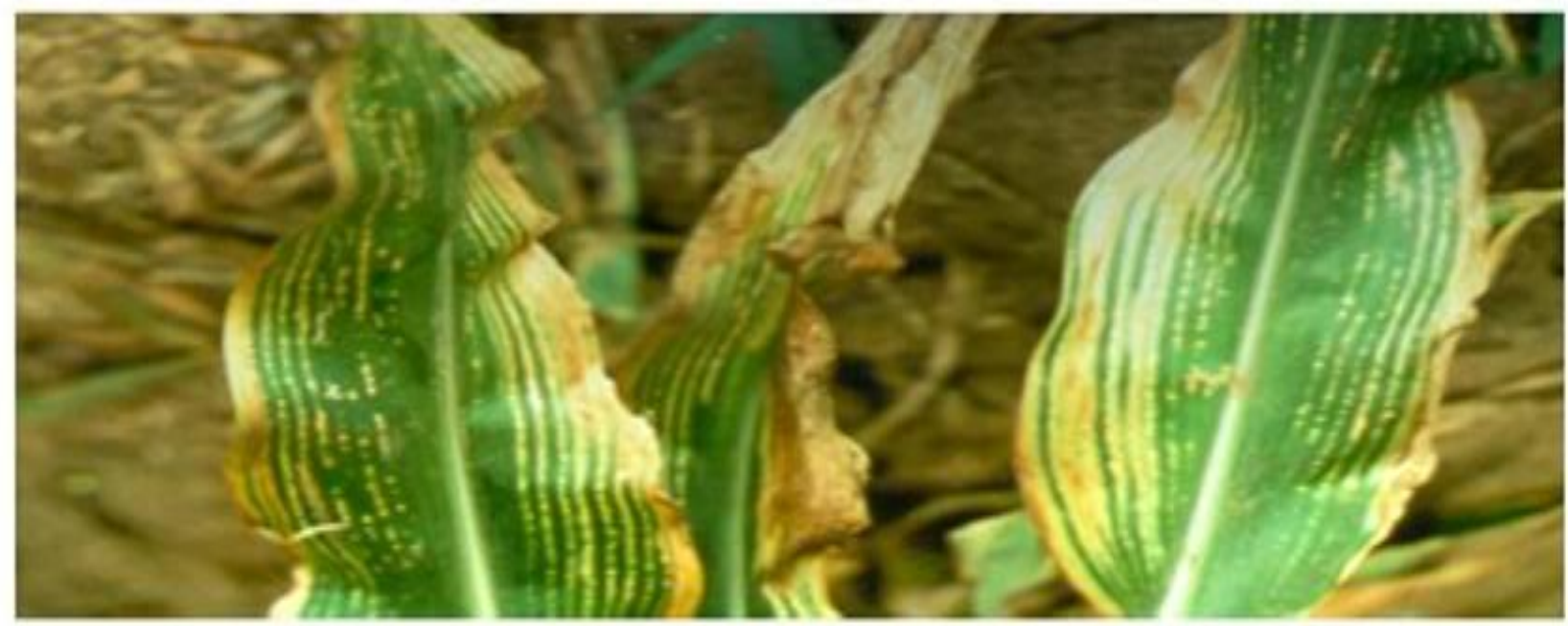

Excess Magnesium

Figuress. Defieieney symptom Magnesium

Magnesium toxicity is not generally seen. Crops grown on heavy montmorillonite clay soils that have been poorly fertilized with potassium may exhibit excesses of magnesium in their tissue. Higher tissue levels of magnesium are usually found in the older leaves. High Mg levels may induce $\mathrm{K}$ deficiency (Khan Towhid Osman, 2013).

\subsection{FERTILIZER SOURCE MANAGEMENT OF SECONDARY MACRO NUTRIENTS IN THE SOIL}

Soil Specific Nutrient Management As not all soils are created equal it is appropriate that nutrient applications need to be tailored to the particular soil type in order to achieve the correct nutrient balance required for the growing crop. To implement soil fertility advice for individual soil types at farm level Knowledge of the soils present is required (Stephen Alexander etal, 2016).

Three global trends are responsible for increasing $\mathrm{S}$ deficiencies:

1) The shift in modern fertilizers to more concentrated, higher-analysis forms containing little to no $S$ (a historical byproduct of the manufacturing process);

2) The reduction of sulfur dioxide emissions from burning coal and oil, which decreases atmospheric $\mathrm{S}$ additions; and

3) The steady increase in crop $S$ uptake and removal due to high-yielding varieties and more productive management. Effective management of secondary nutrients requires an understanding of the processes that determine their availability to crops and the methods to manage soils wit inadequate secondary nutrient levels. Because $\mathrm{S}$ is a greater concern for most producers in Montana and Wyoming than $\mathrm{Ca}$ and $\mathrm{Mg}$, it will be discussed first and in greater detail in this module (Nathan Korb, etal 2002).

The main sources of sulfate in the soil are sulfur-containing minerals and organic matter. Gypsum $(\mathrm{CaSO} 4 \cdot 2 \mathrm{H} 2 \mathrm{O})$ is a very common secondary mineral source of sulfur in soils developed from sedimentary parent materials. It is also abundant in soils of the arid and semiarid regions. Pyrite (FeS 
2 ) is another important sulfur-containing mineral associated with shale and coal and in hydromorphic soils of the coastal regions receiving ample sulfate with sea salts and plenty of partially decomposed organic matter for reduction of sulfate. These are acid sulfate or potentially acid sulfate soils. In waterlogged soils, sulfate is reduced to elemental sulfur (S), H 2S , or FeS 2. Upon drainage of the soil, these compounds are again oxidized to sulfuric acids and sulfate salts. Sulfur compounds, thus, participate in redox reactions in soil (Khan Towhid Osman, 2013).

most sulfur, 60-90\%, in soils comes from organic matter, which upon mineralization releases available sulfate slowly. Sulfur is, therefore, concentrated in the topsoil or plow layer. Sulfate mineralization is rapid in warm and well-drained soils. Sulfate can be leached, but the rate of leaching is slower than nitrate. Some sulfate is held by clay colloids (Khan Towhid Osman, 2013).

\section{Fertilizer Source ofsulfur}

Liquid and dry sulfur-containing fertilizer materials are plentiful. In fact, more sulfur- containing fertilizer materials are available to the industry than any other major or secondary plant nutrient.

Ammonium Sulfate. (21-0-0-24S) is one of the oldest sources of ammoniacal nitrogen, manufactured as a by-product of the coking of coal from the steel industry. Ammonium sulfate is also manufactured as a byproduct from metallurgical and chemical operations. Nearly one-fourth of world production comes from caprolactam manufacture, a raw material for the production of synthetic fibers. Three to four pounds of by-product ammonium sulfate are formed for each pound of caprolactam produced. Ammonium sulfate accounts for 4 million tons of plant nutrient sulfur worldwide. This product can be blended with most other dry fertilizers or can be made into a liquid. Ammonium sulfate is a good source of both nitrogen and sulfur, has low hygroscopicity, and is chemically stable. Its use may be undesirable on acidic soils, due to the acid-forming potential (Havlin, et al,2005).

Ammonium Thiosulfate. (12-0-0-26 S) is a clear liquid material with no appreciable vapor pressure containing 12 percent nitrogen and 26 percent sulfur. Ammonium thiosulfate is the most popular sulfur-containing product used in the fluid fertilizer industry. When ammonium thiosulfate is applied to the soil, it decomposes to form colloidal elemental sulfur and ammonium sulfate. Ammonium thiosulfate should not be used in starter fertilizers placed in direct seed contact, because of toxicity to seed (Havlin, et al ,2005).

Potassium Magnesium Sulfate $(0-0-22 \mathrm{~S}-11 \mathrm{Mg})$ is sometimes referred to as $\mathrm{K}-\mathrm{Mag}$, is marketed as a dry material that is 22 percent $\mathrm{K} 2 \mathrm{O}, 22$ percent sulfur, and 11 percent $\mathrm{Mg}$. It is used in mixed fertilizers or sometimes applied alone to supply sulfur and magnesium on soils deficient in these two elements (Havlin, et al ,2005).

Elemental Sulfur (typically 90 to $95 \% \mathrm{~S}$ ) is marketed by several manufacturers. These products are usually 90 percent or higher sulfur content with a small amount of binding material and/or bentonite clay to facilitate blending, application and soil reaction. Concern exists about a vailability of elemental sulfur during the year of application. Before it becomes available for plant uptake, elemental sulfur must first be oxidized by soil microorganisms to sulfate-S and this can be a slow process when surface applied (Havlin, et al ,2005).

Gypsum (analysis varies) is calcium sulfate and is commonly available in a hydrated form containing 18.6 percent sulfur. This material is generally applied in a dry form and is available in a granulated form that can be blended with other materials (Havlin, et al ,2005).

Potassium Sulfate (0-0-50-17S) is usually applied in a dry granular form, is often referred to as sulfate of potash. It contains 50 to 52 percent $\mathrm{K} 2 \mathrm{O}$ and 17 to 18 percent sulfur. Potassium sulfate is used as a $\mathrm{K}$ and sulfur source in potato and tobacco production since these crops are sensitive to large applications of chloride. Potassium sulfate is not commonly available in the marketplace (Havlin, et al ,2005).

\subsubsection{Fertilizer Source of Magnesium}

Dolomitic lime is an economical source of $\mathrm{Mg}$ for acid soils. Potassium-magnesium sulfate (K- Mag, $11 \% \mathrm{Mg}$ ) is an excellent source of magnesium that also supplies sulfur and potassium. It is also the most common fertilizer source used in Kansas and the Great Plains. Other magnesium containing fertilizers include magnesium sulfate (epsom salt, $10 \% \mathrm{Mg}$ ) and magnesium oxysulfate (variable analysis).Sulfate forms of magnesium are more soluble than dolomitic lime and are preferred on soils 
where an immediate crop response is expected (Havlin, et al , 2005).

\section{Fertilizer Source ofCalcium}

Limestone used to correct soul acidity is the predominant source of applied calcium. The amount of calcium added in limestone plus the relatively large amounts of exchangeable calcium in the soil far exceeds the 50-100 lbs/a of calcium commonly removed by crops (Havlin, et al ,2005).

Table 4.Generally Average percentage of chemical content of major sources of calcium magnesium, and sulfur.

Calcium

\begin{tabular}{|l|l|l|l|l|}
\hline Material & Calcium & Magnesium & Sulfur & Other \\
\hline calcitic lime & 31.7 & 3.4 & 0.1 & 0 \\
\hline dolomitic lime & 21.5 & 11.4 & 0.3 & 0 \\
\hline Gypsum & 22.5 & 0.4 & 16.8 & 0 \\
\hline basic slag & 29.0 & 3.4 & 0.3 & No longer a P source \\
\hline
\end{tabular}

Magnesium

\begin{tabular}{|l|l|l|l|l|}
\hline Material & Calcium & Magnesium & Sulfur & Other \\
\hline magnesium sulfate & 2.2 & 10.5 & 14.0 & 0 \\
\hline $\begin{array}{l}\text { sulfate of potash } \\
\text { magnesium }\end{array}$ & 0 & 11.2 & 22.7 & $22 \mathrm{~K} 2 \mathrm{O}$ \\
\hline magnesium oxide & 0 & & & 0 \\
\hline
\end{tabular}

Sulfur
\begin{tabular}{|l|l|l|l|l|}
\hline Material & Calcium & Magnesium & Sulfur & Other \\
\hline ammonium sulfate & 0.3 & 0 & 23.7 & 21 nitrogen \\
\hline potassium sulfate & 0 & 1.2 & 17.6 & 50 K2O \\
\hline Gypsum & 22.5 & 0.4 & 16.8 & 0 \\
\hline magnesium sulfate & 2.2 & 10.5 & 14.0 & 0 \\
\hline zinc sulfate & 0 & 0 & 17.8 & 36.4 zinc \\
\hline Prilled Sulfur & 0 & 0 & $33-99$ & 0 \\
\hline
\end{tabular}

\section{CONCLUSION}

Secondary macronutrients play a very important role in plant growth and development, and thus influence at every stage of plant life. Plant growth and development largely depend on the combination and concentration of mineral nutrients available in the soil. Plants often face significant challenges in obtaining an adequate supply of these nutrients to meet the demands of basic cellular processes due to their relative immobility. A deficiency of any one of them may result in decreased plant productivity and/or fertility. Symptoms of nutrient deficiency may include stunted growth, death of plant tissue, or yellowing of the leaves caused by a reduced production of chlorophyll, a pigment needed for photosynthesis. Nutrient deficiency can have a significant impact on agriculture, resulting in reduced crop yield or reduced plant quality. Nutrient deficiency can also lead to reduced overall biodiversity since plants serve as the producers that support most food webs. However, excess and/or deficit of secondary macronutrients may adversely affect the overall growth and performance of plants. Therefore, the cellular status of an element must be tightly regulated. Mineral nutrients are usually obtained from the soil through plant roots, but many factors can affect the efficiency of nutrient acquisition. First, the chemistry and composition of certain soils can make it harder for plants to absorb nutrients.

\section{ACKNOWLEDGEMENT}

The authors acknowledgesGenerally Bahir Dar University, College Of Agriculture and Environmental Sciences, Department of Natural Resource Management. I would like to express my sincere gratitude and appreciation to Prof. YihenewG. Selassie for his excellent guidance and support throughout my Academic life. 49

\section{REFERENCES}

[1] Agricultural Transformation Agency. 2016. Ethiopian soil information system map. Amhara Regional 
State Soil fertility status and fertilizer recommendation.

[2] Alam SM .1999.Nutrient uptake by plants under stress conditions. In: Pessarakli M (ed) Handbook of plant and crop stress, vol 3. Marcel Dekker, New York, pp 285-313.

[3] Blumenthal J, Battenspenrger D, Cassman KG, Mason, KG and A Pavlista .2008 .Importance of nitrogen on crop quality and health. In: Hatfield JL, Folett RF, editors. Nitrogen in the Environment: Sources, Problems and Management, $2^{\text {nd }}$ edition. Elsevier, Amsterdam.

[4] Brady NC and RR Weil .2008.The Nature and Properties of Soils. Revised 14th ed. Pearson Prentice Hall. New Jersey.

[5] Brady N.C. and Weil, R.R. 2017.The nature and properties of soils,15th ed. Prentice Hall, Upper Saddle River, NJ.

[6] Durgesh Kumar Tripathietal ,2014.Role of Macronutrients in Plant Growth and Acclimation. Springr Science-Business Media New York 2014.

[7] Epstein E . 1972. Mineral Nutrition of Plants: Principle and Perspectives. John Wiley and Sons, New York.

[8] Foth HD (1990) Fundamentals of soil science. $8^{\text {th }}$ edn. Wiley, New York. Hafeez B, Khanif YM and M Saleem.2013.Role of zinc in plant nutrition-A review. Am. J. Exp.Agri.; 3(2): 374-391.

[9] Hao X and AP Papadopoulos.2003. Effect of calcium and magnesium on growth, fruit yield and quality in a fall greenhouse tomato crop grown on rockwool.Canad. J. Plant Sci.; 83: 903-912.

[10] Havlin, J.L., J.D. Beaton, S.L.Tisdale, and W.L.Nelson. 1999. Soil Fertility and Fertilizers. $6^{\text {th }}$ Edition.Prentice Hall. Upper Saddle River, NJ. 499 p.

[11] Havin,J.L.,Beaton,J.D.,Tisdale,S.L.,andNelson,W.L.(2005).sulfur,calcium and Magnesium. Soil fertility and fertilizers. An Introduction to Nutrient Management,219-243.

[12] He ZL, Yang XE .2007. Role of soil rhizobacteria in phytoremediation of heavy metal contaminated soils. J Zhejiang UnivSci 8(3):192-207.

[13] Hodges,S.C. (n.d).Soil Fertility basics. soil science extension north Carolina state university. Basic concept Basic concepts.1-75

[14] Hugh Savoy,Nd. fertilizer and their uses. The University of Tennessee, https://www.sci-hub.tw,23-122019

[15] Jamal A, Moon Y and MZ Abdin. 2010. Sulphur- a general overview and interaction with nitrogen. Aust. J. Crop Sci.; 4(7): 523-529.

[16] Jones C and J Jacobsen (2001).Plant nutrition and soil fertility. Nutrient Management Extension Publication 4449-2. Montana State University, 2001.

[17] Khan TowhidOsman .2013 .Soils Principles, Properties and Management. ISBN 978-94-007- 5663-2 (eBook) DOI 10.1007/978-94-007-5663-2 .Springer Dordrecht Heidelberg New York London).

[18] Marschner H. 1986. Mineral nutrition in higher plants. Harcourt Brace. New York.

[19] M. Ray Tucker.1999. Essential plant nutrients.Their presence in North Carolina soils and role in plant nutrition.

[20] Mousavi SR. 2011. Zinc in crop production and interaction with phosphorus. Aust. J. Bas. Appl. Sci.; 5(9): 1503-1509.

[21] Nathan Korb, Clain Jones and Jeff Jacobsen .2002.Secondary Macronutrients: Cycling, Testing and Fertilizer Recommendations. Nutrient Management Module No.6,16. Montana State University.

[22] Nzanza B.2006 .Yield and quality of tomato as influenced by differential $\mathrm{Ca}, \mathrm{Mg}$ and $\mathrm{K}$ nutrition. MSc Thesis. University of Pretoria.Republic of SouthAfrica.

[23] QuirineKetterings ,DougBeegle , Karl Czymmek, Joe Lawrence .2016. NRCCA Soil Fertility \& Nutrient Management, Study Guide, Cornell University.

[24] Rasmussen, P.E. and P.O. Kresge. 1986. Plant Response to Sulfur in the Western United States. p.357-374. In M.A. Tabatabai, (ed.) Sulfur in Agriculture. Agron.Monogr. 27. ASA, CSSA, and SSSA. Madison, WI.

[25] Robert d. munson . 1998.Principles of plant analysis. Taylor \& Francis Group, LLC S.S Rana. 2011. Principles and Practice of Soil Fertility and Nutrient Management. Theory cum Practical,Palampur176062,130. 
[26] Soetan KO, Olaiya OC and OE Oewole .2010.The importance of mineral elements for humans, domestic animals and plants.A review.Afri. J. Food; 4(5): 200-222.

[27] Stephen Alexander,William Burchill1, John Carroll .2016. Major and micro nutrient advice for productive agricultural crops. $4^{\text {th }}$ Edition.Teagasc, Johnstown Castle, Co. Wexford.

[28] Street, HE, Opik, H .1970 .The physiology of flowering plants: their growth and development. Edward Arnold Ltd.

[29] Street JJ, Kidder G .1997.Soils and Plant nutrition, corporative extension service.vol 8. Institute of Food and Agriculture Sciences, University of Florida. SL, pp 1-4.

[30] Subbarao GV, Ito O, Berry WL, Wheeler RM .2003.Sodium-a functional plant nutrient.Crit Rev Plant Sci 22(5):391-416.

[31] Vitousek P .1982. Nutrient cycling and nutrient use efficiency. Am Nat 119:553-572. Yihenew G.Selassie.2015. Are Mineral Fertilizers Panacea for increase in crop yield? Review.Volume 1(1), 84-100.

Citation: Demsew Bekele*and Muluadam Birhan, (2021). "The Impact of secondary Macro Nutrients on Crop Production", International Journal of Research Studies in Agricultural Sciences (IJRSAS), 7(5), pp. 37-51 DOI: http://dx.doi.org/10.20431/2454-6224.9不05005

Copyright: (c) 2021 Authors. This is an open-access article distributed under the terms of the Creative Commons Attribution License, which permits unrestricted use, distribution, and reproduction in any medium, provided the original author and source are credited. 